\title{
Analysis of the association between hand grip strength and functionality in community old people
}

\section{Abstract}

Objective: To analyze the association between hand grip strength (HGS) and physical ability tests by healthy, non-institutionalized old people. Method: This is a cross-sectional research. The sample comprised 36 old people (66.69 \pm 4.84 years), and they all responded two questionaires, one containing a cognitive assessment and another to assess the level of physical activity, in addition to sociodemographic data and health conditions. The HGS was measured using the JAMAR hydraulic dynamometer, and the six-minute walk test (6MWT) and the Timed Up and Go (TUG) test were carried out to assess the submaximal cardiorespiratory capacity during displacement and body mobility. Results: The Pearson coefficient allowed to verify the weak and significant association between the HGS and the 6MWT $(p=0.05)$ and TUG $(p=0.027)$ variables. Conclusion: The HGS showed a weak but significant correlation with the physical ability tests. Therefore, it can be used when contextualized with other variables to assess the functionality in old people in the community.

\section{Keywords: Elderly} Population. Muscle Strength. Muscle strength dynamometer. Physical Functional Performance. Walk test.

\footnotetext{
Universidade Federal de Ciências da Saúde de Porto Alegre, Departamento de Fisioterapia, Programa de Pós-Graduação em Ciências da Reabilitação. Porto Alegre, RS, Brasil.
}

Mariana Edinger Wieczorek' (ID Cislaine Machado de Souza' Patrícia da Silva Klahr' $\mathbb{D}$ Luis Henrique Telles da Rosa' ${ }^{\mathbb{D}}$

The authors declare there are no conflicts of interest in relation to the present study.

No funding was received in relation to the present study.

Correspondence

Mariana Edinger Wieczorek 


\section{INTRODUCTION}

The aging process is naturally followed by several multifactorial and progressive changes. Among these, there are not only physiological and metabolic transformations, but also structural and functional ones. The declines resulting from the aging process as well as the dysfunctions and diseases prevalent in this age group can compromise the functionality, independence and quality of life of the old people $e^{1-4}$.

The loss of muscle mass and consequently muscle strength and power is the main responsible for the deterioration in mobility and functionality of the aging individual ${ }^{2-4}$. Old people have decreased muscle strength due to muscular, neurological, endocrine or environmental mechanisms ${ }^{2,5}$. The decline in strength and mobility of the old person interferes with the performance of essential activities for functional performance, such as walking, sitting, standing up, climbing stairs, among others ${ }^{1,4}$.

The hand grip strength (HGS) has been used as a general indicator of muscle strength and power in clinical practice ${ }^{6,7}$. In addition, the assessment of HGS is used as an indicator of global strength ${ }^{8,9}$ and functionality ${ }^{7,8}$. However, not all studies have been able to demonstrate the existence of significant correlations between HGS and physical capacity ${ }^{10,11}$. There are several ways to assess the physical capacity of old people, often by inference, as it is known that the worse the health status, the greater the negative impact on mobility, the ability to carry out a submaximal task, and the independence of the old person ${ }^{12-15}$.

Muscle groups that are essential to support body weight such as trunk and lower limb stabilizing muscles are usually used to perform functional tests $^{11-13}$. Performance is due to the ability to generate strength in a given test time (slow contraction fibers type I), whereas the HGS assesses the peak muscle strength of the upper groups (fast contraction fibers type II) that are less resistant to fatigue ${ }^{12,13}$. In general, physical ability tests involve tasks requiring postural, mobility, and displacement transfer $\mathrm{r}^{11,13,14,16}$.

There are still gaps in the relation between HGS and the functionality of the old person ${ }^{10,11}$. There are physiological factors related to the aging process concomitant to reduced strength and motor control, such as proprioceptive alterations in the sensory receptors, neuromuscular and vestibular function, and visual acuity, which directly affect mobility, gait performance, and postural control ${ }^{15,16}$. The applicability of HGS as a unique indicator for assessing the physical capacity in people over 60 years old is questionable. The present study aimed to analyze the correlation between HGS and the physical ability tests in healthy old people in the community.

\section{METHOD}

This is an observational study with a crosssectional design approved by the Research Ethics Committee of Universidade Federal de Ciências da Saúde de Porto Alegre under the protocol number $2,137,840 / 2017$. The present study integrates a larger research on the subject of functionality of old people developed at the institution by the Study Group in Rehabilitation (GEReab).

The sample was calculated using the WinPepi software havig the study by Merchant, et al. $2016^{15}$ as a reference, considering a standard deviation of $5.93 \mathrm{~kg}$ for hand grip strength, and adopting an acceptable difference of $2 \mathrm{~kg}$; confidence level of $95 \%$, and significance level set at 5\% ( $p \leq 0.05)$. Therefore, the number of old people should be at least 37 .

The individuals were recruited by social media (Facebook and Instagram), and local publicity actions with flyer distribution (distributed in parks in the city of Porto Alegre, RS, Brazil) and billboards (in the surroundings of the most central area of the City, close to the University). Individuals aged 60 years or over were included. Healthy individuals who had autonomy and independence, and with controlled chronic diseases and physical symptoms were considered for the inclusion criteria ${ }^{17}$. Old people in the postoperative period of any nature, with physical or mental diseases or deficits characterizing a process of pathological aging that prevented the tests were excluded.

The sociodemographic and clinical variables of interest were gender, age, weight and height, body mass index, education, health problems, medication 
use, occupational and social activities, and physical exercise. The Mini Mental State Examination $(\mathrm{MMSE})^{18}$ was applied for to assess the cognition of the old people, with the following cutoff points being used: 18 points for illiterates, 21 for those with education between one and three years, 24 for individuals between four and seven years of formal education, and 26 for people with more than seven years of education. To assess the level of physical activity, the International Physical Activity Questionnaire (IPAQ) ${ }^{19}$, short form, was applied. This version presents seven questions whose information estimates the time spent per week in different domains of physical activity, such as work, means of transportation, domestic activities, recreation, sport or leisure, and time spent sitting. The final classification determines individuals as sedentary, irregularly active, active, and very active ${ }^{20}$.

To ensure the quality of the assessment protocol, the researchers responsible for data collection were properly trained. Both the initial interview and the protocol for test application to the individuals included in the research took place at the Physical Therapy Laboratory of Universidade Federal de Ciências da Saúde de Porto Alegre from January 2018 to July 2019. The hand grip strength test and functional tests were applied on the same day. The individuals participating in the research were informed about the procedures and signed the Informed Consent Form (ICF).

\section{Hand grip strength (HGS)}

A JAMAR portable hydraulic dynamometer ${ }^{21}$ was used to measure the hand grip strength. The individual was measured sitting on a chair with a backrest and no armrests. The shoulder of the limb tested was adducted and in neutral rotation, elbow flexed at 90 degrees, forearm in neutral position, and wrist between 0 and 30 degrees of extension and between 0 to 15 degrees of ulnar deviation ${ }^{6,21,22}$. There was a demonstration of how the test should be performed for the participants to be familiarized with the equipment, then there was a simulation. During the test, there was encouragement by standardized verbal commands. Participants were instructed to contract to the maximum using their dominant hand $^{6,22}$. They were measured three times, and the best performance among the three attempts was the reference ${ }^{6,22}$. There was a rest interval of 30 seconds after each attempt ${ }^{21.22}$. Some factors can hinder the establishment of normative values of HGS, among which can be mentioned gender, age, dominance, time of assessment, body position, and anthropometric characteristics ${ }^{6,21,22}$.

\section{Six-minute walk test (6MWT)}

It measures the maximum distance covered in the 6-minute period, and is commonly used to assess submaximal cardiorespiratory capacity during activities requiring displacement ${ }^{14}$. The test was applied as recommended by the American Thoracic Society ${ }^{23}$; briefly: the subjects were instructed to walk from side to side in a 30-meter long hall for a period of 6 minutes, being instructed to walk as fast as possible, but without running. Before starting the test, blood pressure (BP), peripheral oxygen saturation (SpO2), Borg scale, heart rate (HR), and respiratory rate (RR) were measured. The variables were measured again after the end of the test. The evaluator walked throughout the test a little behind the individual who was monitored throughout the period by the oximeter. During the test, all participants were verbally encouraged in a pre-established manner every one minute. Anyone feeling tired could slow down the pace or even stop, if necessary, but the timer was not stopped during rest. After 6 minutes, the individual was instructed to stop, and the distance traveled on the last lap was measured.

\section{Timed Up and Go (TUG) Test}

It indicates the functional mobility, the performance of which is related to the gait, postural and direction changes during the walk, being evaluated throughout the time spent on the test $^{13,14}$. For the test, a chair with a backrest was positioned, and the individual was asked to get up from the chair without hand support, cover a distance of 3 meters, turn around, and return to sit on the chair again. During the test, the timer was started when the participant got up from the 
chair, and interrupted when their back toutched the backrest. TUG time was measured in seconds (s). Each participant could practice beforewards to become familiar with the task ${ }^{24}$.

Quantitative variables were expressed as mean \pm standard deviation. Initially, the Shapiro-Wilk test was carried out to verify the normality of the data, which was confirmed $(p>0.05)$. The descriptions of the qualitative variables were expressed in absolute and relative frequencies. Pearson's correlation coefficient was used to verify the correlation between the HGS and the 6MWT and TUG physical ability tests. To compare the other variables of the tests, the Student's t test was used for dependent samples. The level of significance adopted was $p \leq 0.05$.

\section{RESULTS}

Table 1 lists the characteristics of the sample studied. All survey participants declared to be retired or pensioners; of these, $21(58.33 \%)$ reported having another occupation, and $3(8.33 \%)$ informal work. The $26(72.22 \%)$ old people participating in social activities reported having mostly religious commitments and participation in craft groups.

Table 1. Characterization of the sample of 36 healthy old people. Porto Alegre, RS, 2019.

\begin{tabular}{|c|c|}
\hline Quantitative variables & Mean and $\mathrm{SD} \pm$ \\
\hline Age (years) & $66,69( \pm 4,84)$ \\
\hline Height (m) & $1,6( \pm 0,08)$ \\
\hline Weight (kg) & $76,85( \pm 14,4)$ \\
\hline $\mathrm{BMI}\left(\mathrm{Kg} / \mathrm{m}^{2}\right)$ & $29,9( \pm 5,26)$ \\
\hline Years of education & $15,21( \pm 3,7)$ \\
\hline MMSE & $24( \pm 9)$ \\
\hline Qualitative variables & $\mathrm{n}(\%)$ \\
\hline \multicolumn{2}{|l|}{ Gender } \\
\hline Female & $30(83,33)$ \\
\hline Male & $6(16,67)$ \\
\hline \multicolumn{2}{|l|}{ Activities } \\
\hline Occupation & $21(58,33)$ \\
\hline Informal employment & $3(8,33)$ \\
\hline Social activities & $26(72,22)$ \\
\hline Leisure activities & $9(25,00)$ \\
\hline \multicolumn{2}{|l|}{ Physical exercise } \\
\hline Takes walks & $7(19,44)$ \\
\hline Lifts weight & $1(2,78)$ \\
\hline \multicolumn{2}{|l|}{ IPAQ classification } \\
\hline Very Active & $2(5,55)$ \\
\hline Active & $3(8,33)$ \\
\hline Irregularly active A & $10(27,78)$ \\
\hline Irregularly active B & $17(47,22)$ \\
\hline Sedentary & $4(11,11)$ \\
\hline
\end{tabular}

Many quantitative variables were expressed as Mean $=$ mean and $\mathrm{SD}=$ standard deviation. Qualitative variables expressed in $\mathrm{n}=$ absolute frequency and $\%=$ relative frequency. BMI = Body Mass Index; MMSE $=$ Mini Mental State Examination; IPAQ = International Physical Activity Questionnaire. 
The results for the tests are shown in Table 2. All old people participating in the survey were able to complete the physical ability tests without interruption. Table 3 shows the variables analyzed in the GMWT pre and post test, and the scores show that there was an adequate response to exercise.
Table 4 shows the correlation between the HGS and the results of the 6MWT (distance covered in meters) and in the TUG (travel time in seconds). The results of Pearson's coefficient revealed the existence of a weak but significant correlation between HGS and functionality measured in the physical ability tests.

Table 2. Results of the Hand grip strength and Physical ability tests. Porto Alegre, RS, 2019.

\begin{tabular}{ll}
\hline Tests & Mean and SD \pm \\
\hline Hand grip strength (kgf) & $30,22( \pm 8,36)$ \\
Six-minute Walk Test (m) & $455,17( \pm 90,41)$ \\
Timed Up and Go (s) & $6,89( \pm 1,6)$ \\
\hline
\end{tabular}

Mean $=$ arithmetic mean, and $\mathrm{SD}=$ standard deviation.

Table 3. Variables of the 6-minute walk test in the pre and post test moments. Porto Alegre, RS, 2019.

\begin{tabular}{llll}
\hline Variables & $\begin{array}{l}\text { Pre-test } \\
\text { Mean and SD } \pm\end{array}$ & $\begin{array}{l}\text { Post-test } \\
\text { Mean and SD } \pm\end{array}$ & $* p$ \\
\hline SpO2 $(\%)$ & $97( \pm 1,84)$ & $97,68( \pm 1,20)$ & 0,010 \\
Heart rate $(\mathrm{bpm})$ & $77,15( \pm 10,68)$ & $82,5( \pm 10,62)$ & 0,004 \\
SBP (mmHg) & $131,88( \pm 16,71)$ & $140,35( \pm 19,79)$ & 0,003 \\
DBP (mmHg) & $77,5( \pm 9,77)$ & $82,18( \pm 10,01)$ & 0,003 \\
RF (irpm) & $17,5( \pm 2,69)$ & $20,56( \pm 3,26)$ & 0,000 \\
\hline
\end{tabular}

$\mathrm{SpO} 2$ = Oxygen saturation; $\mathrm{HR}=$ heart rate; $\mathrm{SBP}=$ systolic blood pressure; $\mathrm{DBP}=$ diastolic blood pressure; $\mathrm{RF}$ = respiratory frequency; *Student's $t$ test for paired samples; $p=$ level of significance.

Table 4. Correlation between hand grip strength and physical ability tests in 36 old people. Porto Alegre, RS, 2019.

\begin{tabular}{lll}
\hline \multirow{2}{*}{ Pearson's Correlation Test } & \multicolumn{2}{l}{ Hand grip strength } \\
\cline { 2 - 3 } & $\mathrm{r}$ & $p$ \\
\hline Six-minute Walk Test & 0,324 & 0,05 \\
Timed Up and Go & $-0,385$ & 0,027 \\
\hline
\end{tabular}

$\mathrm{r}=$ Pearson's correlation; $p=$ level of significance.

\section{DISCUSSION}

By analyzing the results of the present study, we can see that the HGS measure can be associated with the functional physical capacity of the old person in the community. Other studies have already shown positive associations between HGS and functional tasks. In their study, Geraldes et al. ${ }^{10}$ show a moderate correlation between HGS and performance in motor tasks. This association proved to be stronger with the set of tests than with each one taken in isolation. This result is probably due to the study also presents function tests with fine motor skills such as taking and putting the key in a lock and taking and replacing a lamp in a nozzle, in addition to the physical ability tests such as TUG and the gait speed test, which also require some skills and strength of the upper limb.

Similarly, Oliveira et al. ${ }^{7}$ showed in their study that the HGS serves as an indicator of functionality 
related to ADL's and IADL's. The results were obtained with the use of the Barthel Index and the Lawton and Brody Scale, which classify the activities carried out by the old people according to a score. Many of the motor activities present on the scales such as feeding, locomotion, personal hygiene, administration of social, economic and self-care functions are verified by means of interviews or simple tests of functional performance within the usual environment where the old person lives.

In scientific research and clinical practice, HGS and leg extension strength (isokinetic dynamometer) seem to be adequate for the global tracking of muscle weakness in the old people ${ }^{16,25}$. However, there is a differential decline in the motor units between static and dynamic muscle fibers, and asymmetric loss of muscle trophism with muscular atrophy of the lower limb exceeding the upper limb ${ }^{11,26}$. In addition, some conditions prevalent in the old people such as pain complaints, biomechanical alterations, neuropathies, deformities, among others, can also influence the results obtained with dynamometry ${ }^{11}$.

Felicio, et al. ${ }^{11}$ observed that the HGS did not show any correlation between the variables assessed by the isokinetic dynamometer - considered the gold standard - in assessing muscle strength, showing that HGS should not be used indiscriminately since other factors must also be taken into account regarding the use of HGS as a representative measure of functionality.

On the other hand, in the study by Alonso et al. ${ }^{16}$, the lowest HGS was correlated with the worst performance of mobility and dynamic postural balance in the TUG, and significantly correlated with muscle strength in the lower limbs, suggesting that the HGS could be used as a substitute indicator of global muscle strength for screening among older women.

Muscle strength is not the only determinant decline in functionality. According to the World report on aging and health, $2015^{27}$, functionality is also characterized by intrinsic factors refering to the physical and mental characteristics that the individual develops during the course of their life, and this is influenced in turn by extrinsic factors determined by the context of life in which the old person is inserted, and built through personal relationships, attitudes, values, systems, and health and social policies reflecting as positive or negative factors in their functionality.

Regarding the characteristics of the sample, only 3 $(8.33 \%)$ old people were classified as physically active, and $2(5.55 \%)$ as very active. According to Lenardt et al. ${ }^{28}$, men and women over 60 with a lower level of physical activity also have less muscle mass, and consequently a higher prevalence of physical disability. In this sense, Martin et al. ${ }^{29}$ argue that physical inactivity can contribute to the functional loss of the old people due to the physiological alteration of muscle mass and strength, thus decreasing the physical performance and fitness.

The present study with healthy old people compared to cutoff points already established in the literature showed that the mean values of HGS 30.22 $\operatorname{Kgf}( \pm 8.36)$ and physical ability tests 6MWT $455.17 \mathrm{~m}$ $( \pm 90.41)$ and TUG $6.89 \mathrm{~s}( \pm 1.6)$ were considered relatively high for this population ${ }^{30-32}$. This is probably due to the significant number of old people in the study participating in social activities - $26(72.22 \%)$ - and having some occupation - 21 (58.33\%) -, which can indirectly predict greater physical capacity, thus increasing the HGS and test performance. Exercising in a systematic way contributes positively to higher levels of $\mathrm{HGS}^{30,33}$ and physical fitness ${ }^{28.29}$. However, an active behavior in other domains and activities, even if not structured but performed spontaneously during the day especially at leisure, can positively influence in the same way ${ }^{33}$.

Exploring a tool of easy and quick applicability by health professionals for tracking the functionality of the old person is relevant. The present study excelled for its methodological rigor, quality of description, and application of the tests, as well as the selection and inclusion criteria in the research and collection of information to characterize the sample. However, a possible limitation must be considered: the fact that women correspond to almost the entire sample. This confirms the Brazilian demographic pattern in which the absolute number of women over 60 years old is greater than that of men ${ }^{34}$. HGS values are significantly higher among men, whereas the decline over the years does not occur homogeneously between genders, being greater in men than in 
women $^{35}$. Thus, studies with more homogeneous samples and stratification by gender are suggested.

\section{CONCLUSION}

The hand grip strength presented a weak but significant correlation with the physical ability tests.
Therefore, it may be one of the factors to contribute to the outcome of functionality, but it should be used with caution to assess functionality in old people in the community. In view of the biopsychosocial context involving these individuals, the measure can be used when contextualized with other variables.

Edited by: Yan Nogueira Leite de Freitas

\section{REFERENCES}

1. Vieira MCA, Souza CF, Câmara SMA, Matos GSR, Moreira MA, Maciel ACC. Relação entre força de preensão manual e força de membro inferior em mulheres de meia idade: um estudo transversal. Rev Bras Ativ Fis Saúde. 2015;20(5):467-75.

2. Araújo MLM, Fló CM, Muchale SM. Efeitos dos exercícios resistidos sobre o equilíbrio e a funcionalidade de idosos saudáveis: artigo de atualização. Fisioter Pesqui. 2010;17(3):277-83.

3. Mazo GZ, Liposcki DB, Ananda C, Prevê D. Condições de saúde, incidência de quedas e nível de atividade física dos idosos. Rev Bras Fisioter. 2007;11(6):437-42.

4. Mendonça CS, Moura SKMSF, Lopes DT. Benefícios do treinamento de força para idosos: revisão bibliográfica. Rev Campo Saber. 2018;4(1):74-87.

5. Martinez BP, Camelier FWR, Camelier AA. Sarcopenia em idosos: um estudo de revisão. Rev Pesqui Fisioter. 2014;4(1):62-70.

6. Dias JA, Ovando AC, Külkamp W, Junior NGB. Força de preensão palmar: métodos de avaliação e fatores que influenciam a medida. Rev Bras Cineantropom Desempenho Hum. 2010;12(3):209-16.

7. Oliveira EN, Santos KT, Reis LA. Força de preensão manual como indicador de funcionalidade em idosos. Rev Pesqui Fisioter. 2017;7(3):384-92.

8. Mattioli RA, Cavalli AS, Ribeiro JAB, Silva MC. Associação entre força de preensão manual e atividade física em idosos hipertensos. Rev Bras Geriatr Gerontol. 2015;18(4):881-91.

9. Santos LB, Vilela ABA, Santos CA, Lessa RS, Rocha SV. Sensibilidade e especificidade da força de preensão manual como discriminador de risco para multimorbidades em idosos. Cad Saúde Colet. 2018;26(2):146-52.
10. Geraldes AAR, Oliveira ARM, Albuquerque RB, Carvalho JM, Farinatti PTV. A Força de Preensão Manual é Boa Preditora Do Desempenho Funcional de Idosos Frágeis: um Estudo Correlacional Múltiplo. Rev Bras Med Esporte 2008;14(1):12-6.

11. Felicio DC, Pereira DS, Assumpção AM, JesusMoraleida FR, Queiroz BZ, Silva JP, et al. Poor correlation between handgrip strength and isokinetic performance of knee flexor and extensor muscles in community-dwelling elderly women. Geriatr Gerontol Int. 2014;14:185-9.

12. Santos PHG, Pereira JE, Soares WN, Colato H. Potência muscular e sua relação com a autonomia funcional de idosos participante de programas sociais de um município da Amazônia Legal. Rev Bras Prescriç Fisiol Exerc. 2018;12(75):488-95.

13. Wamsera EL, Valderramas SR, Paula JA, Schieferdecker MEM, Amarante TP, Pinotti F, et al. Melhor desempenho no teste timed up and go está associado a melhor desempenho funcional em idosas da comunidade. Geriatr Gerontol Aging 2015;9(4):138-43.

14. Pedrosa R, Holanda G. Correlação entre os testes da caminhada, marcha estacionária e TUG em hipertensas idosas. Rev Bras Fisioter. 2009;13(3):252-6.

15. Merchant RA, Banerji S, Singh G, Chew E, Poh CL, Tapawan SC, et al. Is Trunk Posture in Walking a Better Marker than Gait Speed in Predicting Decline in Function and Subsequent Frailty? J Am Med Dir Assoc. 2016;17(1):65-70.

16. Alonso AC, Ribeiro SM, Luna NMS, Peterson MD, Bocalini DS, Serra MM, et al. Association between handgrip strength, balance, and knee flexion/ extension strength in older adults. PLoS One. 2018;13(6):e0198185. 
17. Valer DB, Bierhals CCBK, Aires M, Paskulin LMG. O significado de envelhecimento saudável para pessoas idosas vinculadas a grupos educativos. Rev Bras Geriatr Geronto.1 2015;18(4):809-19.

18. Melo DM, Barbosa AJG. O uso do Mini-Exame do Estado Mental em pesquisas com idosos no Brasil: uma revisão sistemática. Ciênc Saúde Colet. 2015;20(12):3865-76.

19. Matsudo S, Araujo T, Matsudo V, Andrade D, Andrade E, Oliveira LC, et al. Questionário internacional de atividade física (IPAQ): estudo de validade e reprodutibilidade no Brasil. Rev Bras Ativ Fis Saúde. 2001;6(2):5-18.

20. Kolchraiber FC, Rocha JS, César DJ, Monteiro OO, Frederico GA, Gamba MA. Nível de atividade física em pessoas com diabetes mellitus tipo 2. Rev Cuid. 2018;9(2):2105-16.

21. Reis MM, Arantes PMM. Medida da força de preensão manual - validade e confiabilidade do dinamômetro saehan. Fisioter Pesqui. 2011;18(2):176-81.

22. Figueiredo IM, Sampaio RF, Mancini MC, Silva FCM, Souza MAP. Teste de força de preensão utilizando o dinamômetro Jamar. Acta Fisiatr. 2007;14(2):104-10.

23. ATS Committee on Proficiency Standards for Clinical Pulmonary Function Laboratories. ATS statement: guidelines for the six-minute walk test. Am J Respir Crit Care Med. 2002;166:111-7.

24. Bennell K, Dobson F, Hinman R. Measures of physical performance assessments. Arthritis Rheumatol. 2011;63(11):350-70.

25. Riviati N, Setiati S, Laksmi PW, Abdullah M. Factors Related with Handgrip Strength in Elderly Patients. Indones J Intern Med. 2017;49(3):215-9.

26. Mitchell WK, Williams J, Atherton P, Larvin M, Lund J, Narici M. Sarcopenia, Dynapenia, and the Impact of Advancing Age on Human Skeletal Muscle Size and Strength; a Quantitative Review. Front Physiol. 2012;3:260.
27. World Health Organization. World report on ageing and health [Internet]. Geneva: WHO. Available from: https://apps.who.int/iris/handle/10665/186463

28. Lenardt MH, Binotto MA, Carneiro NHK, Cechinel C, Betiolli SE, Lourenço TM. Força de preensão manual e atividade física em idosos fragilizados. Rev Esc Enferm. 2016;50(1):88-94.

29. Martin FG, Nebuloni CC, Najas MS. Correlação entre estado nutricional e força de preensão palmar em idosos. Rev Bras Geriatr Gerontol. 2012;15(3):493-504.

30. Cruz-Jentoft AJ, Bahat G, Bauer J, Boirie Y, Bruyère $\mathrm{O}$, Cederholm T, et al. Writing Group for the European Working Group on Sarcopenia in Older People 2 (EWGSOP2). Sarcopenia: revised European consensus on definition and diagnosis. Age Ageing. 2018;1-16.

31. Britto RR, Sousa LAP. Teste de caminhada de seis minutos uma normatização brasileira. Fisioter Mov.2006;19(4):49-54.

32. Rodrigues RAS, Teodózio MM, Espinosa MM, Fett WCR, Melo CD, Fett CA. Timed up and go test and self-perceived health in elderly: population-based study. Rev Bras Cineantropom Desempenho Hum. 2018;20(3):247-57.

33. Lima TR, Silva DAS, Kovaleski DF, GonzálezChica DA. Associação da força muscular com fatores sociodemográficos e estilo de vida em adultos e idosos jovens no Sul do Brasil. Ciênc Saúde Colet. 2018;23(11):3811-20.

34. Sousa NFS, Lima MG, Cesar CLG, Barros MBA. Envelhecimento ativo: prevalência e diferenças de gênero e idade em estudo de base populacional. Cad Saúde Pública. 2018;34(11):e00173317.

35. Wearing J, Konings P, Stokes M, Bruin ED. Handgrip strength in old and oldest old Swiss adults: a crosssectional study. BMC Geriatr. 2018;18:266. 